\title{
Basement Data of the Terrestrial Radionuclide Level of Abuja Federal Capital Territory, (FCT), Nigeria
}

\author{
Ayodeji Awodugba ${ }^{1}$, Adetayo Abioye ${ }^{1}$, Dauda Adekunle ${ }^{1}$, Omowumi Ologun $^{1}$, Isiaka Oyekunle ${ }^{1}$, Ola- \\ tunde Oni ${ }^{1}$, Pascal Tchokossa ${ }^{2}$
}

\author{
${ }^{1}$ Department of Pure \& Applied Physics, Ladoke Akintola University of Technology, Ogbomoso, Nigeria; ${ }^{2}$ Centre for Energy Re- \\ search and Development, Obafemi Awolowo University, Ile-Ife, Nigeria. \\ Email: aoawodugba@lautech.edu.ng
}

Received October $18^{\text {th }}, 2010$; revised January $18^{\text {th }}, 2011$; accepted March $16^{\text {th }}, 2011$.

\begin{abstract}
A total of 30 samples were collected from six different locations from of Abuja Federal Capital Territory (FCT), the administrative capital of Nigeria which is situated in the central part of the country. The samples which were thoroughly prepared following known dosimetry procedures were analyzed for ${ }^{40} \mathrm{~K},{ }^{238} \mathrm{U}$ and ${ }^{232} \mathrm{Th}$ by the method of Gamma ray spectrometry using NaI(TL) detector coupled to a multichannel analyzer. The activity concentrations in the top soils in these locations for ${ }^{40} \mathrm{~K},{ }^{238} \mathrm{U}$ and ${ }^{232} \mathrm{Th}$ range from $301 \pm 26.52$ to $928.84 \pm 80.57$, Not detectable $(N D)$ value to 27.68 \pm 8.21 and $4.65 \pm 1.46$ to $22.48 \pm 5.26$ respectively. The average absorbed dose rate and the annual effective dose equivalent were found to be $40.33 n G y h^{-1}$ and $49.46 \mu S v$ respectively. The value of annual effective dose equivalent is low compared to the world average of $70 \mu S v$ specified by UNSCEAR for an outdoor effective dose, hence the chances of radiological hazards to the health of the populace are generally low.
\end{abstract}

Keywords: Gamma Ray Spectrometry, Soil, Radionuclides, Abuja FCT, Nigeria

\section{Introduction}

The occurrence of natural radionuclide in soil depends primarily on the geological and geographical conditions, and appears at different levels in the soil of each region in the world [1-5]. For example, higher levels of radiation are associated with igneous rock such as granite and lower levels with sedimentary rocks. However, some shales and phosphate rocks have relative high content of those radionuclides [6-7]. The composition of these soils and rocks in which the natural radionuclides which are primarily ${ }^{238} \mathrm{U},{ }^{232} \mathrm{Th}$ and ${ }^{40} \mathrm{~K}$ are contained are the major source of the terrestrial component of the natural background radiation and contributes significantly to the total dose from natural sources.

Abuja, the federal capital city of Nigeria which is home to about 800,000 people with ever increasing rural to urban migration rate is located between latitude $8^{\circ} 34^{\prime} \mathrm{N}$, longitude $7^{\circ} 10^{\prime} \mathrm{E}$ and latitude $9^{\circ} 14^{\prime} \mathrm{N}$, longitude $7^{\circ} 34^{\prime} \mathrm{E}$ and has a land area of $713 \mathrm{~km}^{2}$ and density of $1091.9 \mathrm{~km}^{-2}$. The city is also witnessing aggressive construction works to provide houses for this influx of people. ome papers have been published on the radioactivity level in some regions of Nigeria like [8-12] and more recently on the neutron activation analysis of soil and leaf samples from different parts of Abuja Metropolis [13-14] there is, however, no data is available for radionuclides content in soil samples in this city from the survey of literature and authors' knowledge. This work therefore focuses on the measurement of decay products of the ${ }^{238} \mathrm{U}$ and ${ }^{232} \mathrm{Th}$ series as well as of the primordial radionuclide ${ }^{40} \mathrm{~K}$. The baseline data of this type will certainly be of importance in making estimations of population exposures.

The map of Abuja FCT showing the locations from where the soil samples were collected is shown in Figure 1 below.

\section{Materials and Method}

30 samples from the six districts of the Abuja Federal Capital territory were collected from top soil up to a depth of about $15 \mathrm{~cm}$. The description of the samples is as below; 1-Municipal area council, 2-Kwali area council, 3-Abaji area council, 4-Kuje area council, 5-Gwagwal- 


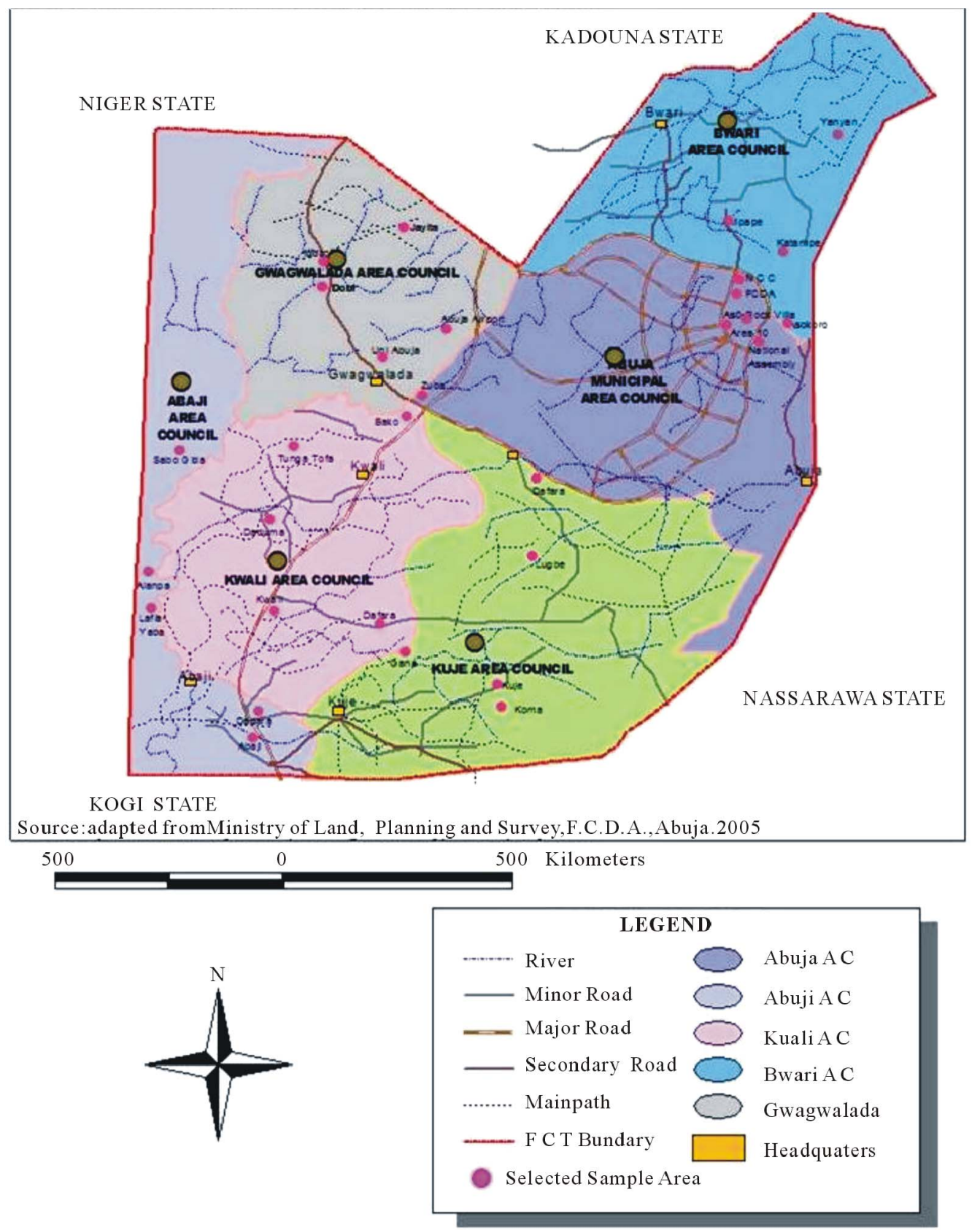

Figure 1. Sampling locations in the municipal council areas of Abuja city.

ada area council and 6-Bwari area council for the six area councils while S1a-FCDA, S1b-NCC, S1c-National Assembly, S1d-Aso-rock Villa, S1e-Area 10 Garki, S2aBako, S2b-Danduma, S2c-Darfa, S2d-Tunga Tofa, S2eKwali, S3a-Dapara, S3b-Sabo Gida, S3c-Abaji, S3dLafia-Yaba, S3e-Alampa, S4a-Gana, S4b-Koma, S4cLugbe, S4d-Kuje, S4e-Dafara, S5a-Dobi, S5b-Abuja airport, S5c-Iddo, S5d-University of Abuja, S5e-Jalita, S6a-Katampe, S6b-Aya Asokoro, S6c-Yanyan, S6dMpape, S6e-Zuba are the samples collected from the exact locations in the six area councils. Grass and pieces of wood were physically eliminated from the samples while pebbles and other unwanted sediments were sieved witha $2 \mathrm{~mm}$ mesh and store in plastic bags pending analysis. All soil samples were dried at $100^{\circ} \mathrm{C}$ for 1.5 hours and kept in air-tight containers of $3 \mathrm{~cm}$ in diameter and $8 \mathrm{~cm}$ in height for about 28 days in plastic containers previously washed and rinsed with diluted sulfuric acid before analysis with the gamma-spectrometer [15] to ensure secular equilibrium between ${ }^{227} \mathrm{Ra}$ and ${ }^{228} \mathrm{Th}$ with their 
daughter products. Measurements on soil samples were carried out with a NaI(TL) detector which was connected to a multichannel analyzer. The same geometry was used for each sample, which was counted in sealed containers for $10 \mathrm{hrs}(36,000 \mathrm{~s})$. For calibration, a $500 \mathrm{cc}$ sand standard radionuclide source was prepared using $0.07721 \mathrm{~g}$ measured gravimetrically from a master radionuclide solution source which was calibrated using a $\mathrm{NaI}$ (TL) gamma spectrometer system. The gamma spectroscopy analysis was based on a computer program which matched gamma energy at various energy levels to a library of possible isotopes. ${ }^{232} \mathrm{Th}$ concentration in soil was determined by the $911 \mathrm{keV}$ gamma lines of ${ }^{228} \mathrm{Ac}$ while the ${ }^{238} \mathrm{U}$ concentrations were determined by the $609 \mathrm{keV}$ gamma lines of ${ }^{214} \mathrm{Bi}$. The activity concentration of ${ }^{40} \mathrm{~K}$ was determined from the peak areas at $1460 \mathrm{keV}$.

The total absorbed dose rate in air, $\mathrm{D}\left(\mathrm{nGyh}^{-1}\right)$ due to a partial evaluation of the radiological hazard posed by the exposure to these estimated radioactivity concentrations at $0.1 \mathrm{~m}$ above the ground was estimated using the empirical formula [16].

$$
\mathrm{D}=0.042 \mathrm{~A}_{\mathrm{k}}+0.428 \mathrm{~A}_{\mathrm{u}}+0.666 \mathrm{~A}_{\mathrm{Th}}
$$

where $A_{k}, A_{u}$, and $A_{T h}$ are the specific activity concentration for $\mathrm{K}, \mathrm{U}$ and $\mathrm{Th}$ respectively.

Also, using an outdoor occupancy factor of 0.20 and the conversion factor of $0.70 \mathrm{SvGy}^{-1}$ (UNSCEAR, 1988), the annual effective dose equivalent (AEDE) from the calculated outdoor terrestrial gamma radiation at $1 \mathrm{~m}$ above the ground in Abuja FCT were calculated using the relation

$$
A E D E=A D R A \times D C F \times O F \times T
$$

where $\mathrm{T}$ is $8760 \mathrm{~h}$.

\section{Results}

\subsection{Radionuclide Levels of Soil Samples}

Table 1 shows the dry-weight activity concentrations of

\begin{tabular}{|c|c|c|c|c|}
\hline $\begin{array}{l}\text { Municipal Area } \\
\text { Council }\end{array}$ & $\begin{array}{l}\text { Samples collected } \\
\text { In location }\end{array}$ & $\begin{array}{c}{ }^{40} \mathrm{~K}^{-1} \\
\left(\mathrm{BqKg}^{-1}\right)\end{array}$ & $\begin{array}{c}{ }^{238} \mathrm{U}\left({ }^{226} \mathrm{U}\right) \\
\left(\mathrm{BqKg}^{-1}\right)\end{array}$ & $\begin{array}{c}\left.{ }^{232} \mathrm{Th}^{228} \mathrm{Th}\right) \\
\left(\mathrm{BqKg}^{-1}\right)\end{array}$ \\
\hline \multirow{5}{*}{$\mathrm{S} 1$} & S1a & $412.10 \pm 36.06$ & $15.93 \pm 2.79$ & $18.83 \pm 3.98$ \\
\hline & $\mathrm{S} 1 \mathrm{~b}$ & $503.18 \pm 43.88$ & $24.10 \pm 4.56$ & $22.48 \pm 5.26$ \\
\hline & $\mathrm{S} 1 \mathrm{c}$ & $801.56 \pm 69.59$ & $8.91 \pm 2.11$ & $13.78 \pm 3.80$ \\
\hline & S1d & $432.73 \pm 37.77$ & $10.98 \pm 2.41$ & $4.90 \pm 1.03$ \\
\hline & S1e & $529.72 \pm 46.12$ & $7.72 \pm 1.38$ & $4.65 \pm 1.46$ \\
\hline \multirow{5}{*}{$\mathrm{S} 2$} & $\mathrm{~S} 2 \mathrm{a}$ & $760.69 \pm 66.06$ & $16.91 \pm 4.06$ & $13.49 \pm 3.54$ \\
\hline & $\mathrm{S} 2 \mathrm{~b}$ & $928.84 \pm 80.57$ & $13.07 \pm 5.94$ & $14.78 \pm 2.61$ \\
\hline & $\mathrm{S} 2 \mathrm{c}$ & $587.08 \pm 51.09$ & $5.63 \pm 1.90$ & $10.31 \pm 2.68$ \\
\hline & $\mathrm{S} 2 \mathrm{~d}$ & $645.15 \pm 56.05$ & $21.87 \pm 5.17$ & $12.77 \pm 2.93$ \\
\hline & $\mathrm{S} 2 \mathrm{e}$ & $486.23 \pm 42.37$ & $17.28 \pm 2.43$ & $7.80 \pm 1.58$ \\
\hline \multirow{5}{*}{$\mathrm{S} 3$} & $\mathrm{~S} 3 \mathrm{a}$ & $462.61 \pm 40.37$ & $9.87 \pm 2.27$ & $17.32 \pm 3.75$ \\
\hline & $\mathrm{S} 3 \mathrm{~b}$ & $325.41 \pm 28.65$ & $17.02 \pm 2.86$ & $19.38 \pm 4.20$ \\
\hline & $\mathrm{S} 3 \mathrm{c}$ & $794.44 \pm 68.98$ & $17.16 \pm 4.86$ & $21.86 \pm 4.10$ \\
\hline & $\mathrm{S} 3 \mathrm{~d}$ & $800.78 \pm 69.49$ & $19.81 \pm 4.91$ & $19.99 \pm 5.43$ \\
\hline & $\mathrm{S} 3 \mathrm{e}$ & $409.48 \pm 35.77$ & $11.85 \pm 2.76$ & $9.56 \pm 2.06$ \\
\hline \multirow{5}{*}{$\mathrm{S} 4$} & $\mathrm{~S} 4 \mathrm{a}$ & $622.86 \pm 54.17$ & $24.46 \pm 5.73$ & $21.43 \pm 3.09$ \\
\hline & $\mathrm{S} 4 \mathrm{~b}$ & $375.72 \pm 32.92$ & $20.55 \pm 4.98$ & $11.35 \pm 1.90$ \\
\hline & $\mathrm{S} 4 \mathrm{c}$ & $499.54 \pm 43.58$ & $10.28 \pm 2.97$ & $13.28 \pm 3.55$ \\
\hline & $\mathrm{S} 4 \mathrm{~d}$ & $301.87 \pm 26.52$ & ND & $8.13 \pm 1.77$ \\
\hline & $\mathrm{S} 4 \mathrm{e}$ & $661.71 \pm 57.48$ & $3.07 \pm 0.17$ & $12.22 \pm 3.54$ \\
\hline \multirow{5}{*}{ S5 } & $\mathrm{S} 5 \mathrm{a}$ & $908.17 \pm 78.80$ & $8.28 \pm 1.42$ & $16.46 \pm 4.03$ \\
\hline & $\mathrm{S} 5 \mathrm{~b}$ & $923.57 \pm 80.12$ & $18.92 \pm 4.85$ & $19.96 \pm 2.86$ \\
\hline & $\mathrm{S} 5 \mathrm{c}$ & $739.56 \pm 64.24$ & $27.68 \pm 8.21$ & $6.33 \pm 1.29$ \\
\hline & $\mathrm{S} 5 \mathrm{~d}$ & $709 \pm 61.66$ & $22.89 \pm 5.72$ & $9.25 \pm 2.32$ \\
\hline & $\mathrm{S} 5 \mathrm{e}$ & $494.34 \pm 43.06$ & $18.04 \pm 4.61$ & $9.45 \pm 1.06$ \\
\hline \multirow{5}{*}{ S6 } & S6a & $450.64 \pm 39.35$ & $10.43 \pm 2.33$ & $12.28 \pm 2.54$ \\
\hline & S6b & $492.60 \pm 42.96$ & $10.57 \pm 3.51$ & $18.66 \pm 2.60$ \\
\hline & S6c & $491.47 \pm 42.87$ & $18.47 \pm 4.92$ & $22.33 \pm 3.74$ \\
\hline & S6d & $714.61 \pm 62.05$ & $24.92 \pm 6.19$ & $7.84 \pm 1.87$ \\
\hline & S6e & $587.41 \pm 39.92$ & $8.44 \pm 2.17$ & $9.92 \pm 2.42$ \\
\hline
\end{tabular}

Table 1. Radioactivity concentrations of ${ }^{40} \mathrm{~K},{ }^{238} \mathrm{U}$ series, and ${ }^{232} \mathrm{Th}$ series in Abuja soil samples. 
the main gamma-emitting radionuclides of the $\mathrm{K}, \mathrm{U}$, and Th series in the soil samples. For ${ }^{40} \mathrm{~K}$ concentration, Danduma in Kwali area council has the highest value of (928.84 \pm 80.57$) \mathrm{Bqkg}^{-1}$ while the lowest value of 301.87 \pm 26.52 is found in Kuje in Kuje area council. ${ }^{238} \mathrm{U}$ has its highest and lowest values of $27.68 \pm 8.21$ and ND at Iddo (Gwagwalada area council) and Kuje (Kuje area council) respectively.

NCC has the highest value of ${ }^{232} \mathrm{Th}$ of $22.48 \pm 5.26$ while the lowest value of $4.65 \pm 1.46$ is found in Garki area 10 all in the municipal area council. The mean activity concentrations of ${ }^{40} \mathrm{~K},{ }^{238} \mathrm{U}$ and ${ }^{232} \mathrm{Th}$ in Abuja FCT surface soil samples area are 596.92, 14.84 and $13.36 \mathrm{Bqkg}^{-1}$, respectively.

\subsection{Absorbed Dose Rate in Air (ADRA)}

The results of the total absorbed dose rate at $1.0 \mathrm{~m}$ above the soil are summarized in Table 2 . It varies between $18.09-60.20 \mathrm{nGyh}^{-1}$ with an average of $40.33 \mathrm{nGyh}^{-1}$. The highest dose rate was recorded at location 22 with absorbed dose rate of $60.20 \mathrm{nGyh}^{-1}$ which also revealed the overall highest contribution in activity concentration for all the radionuclides identified.

\subsection{Annual Effective Dose Equivalent (AEDE)}

Arising from this, the AEDE were found to be between 22.19 and $73.82 \mu \mathrm{Sv}$ for Kuje and airport respectively while the average AEDE of $49.46 \mu \mathrm{Sv}$ is recorded.

Table 2. Radioactivity concentrations of ${ }^{40} \mathrm{~K}$, ${ }^{238} \mathrm{U}$ series, and ${ }^{232} \mathrm{Th}$ series in Abuja soil samples, the absorbed dose rates from gamma radiation and the annual effective dose equivalent.

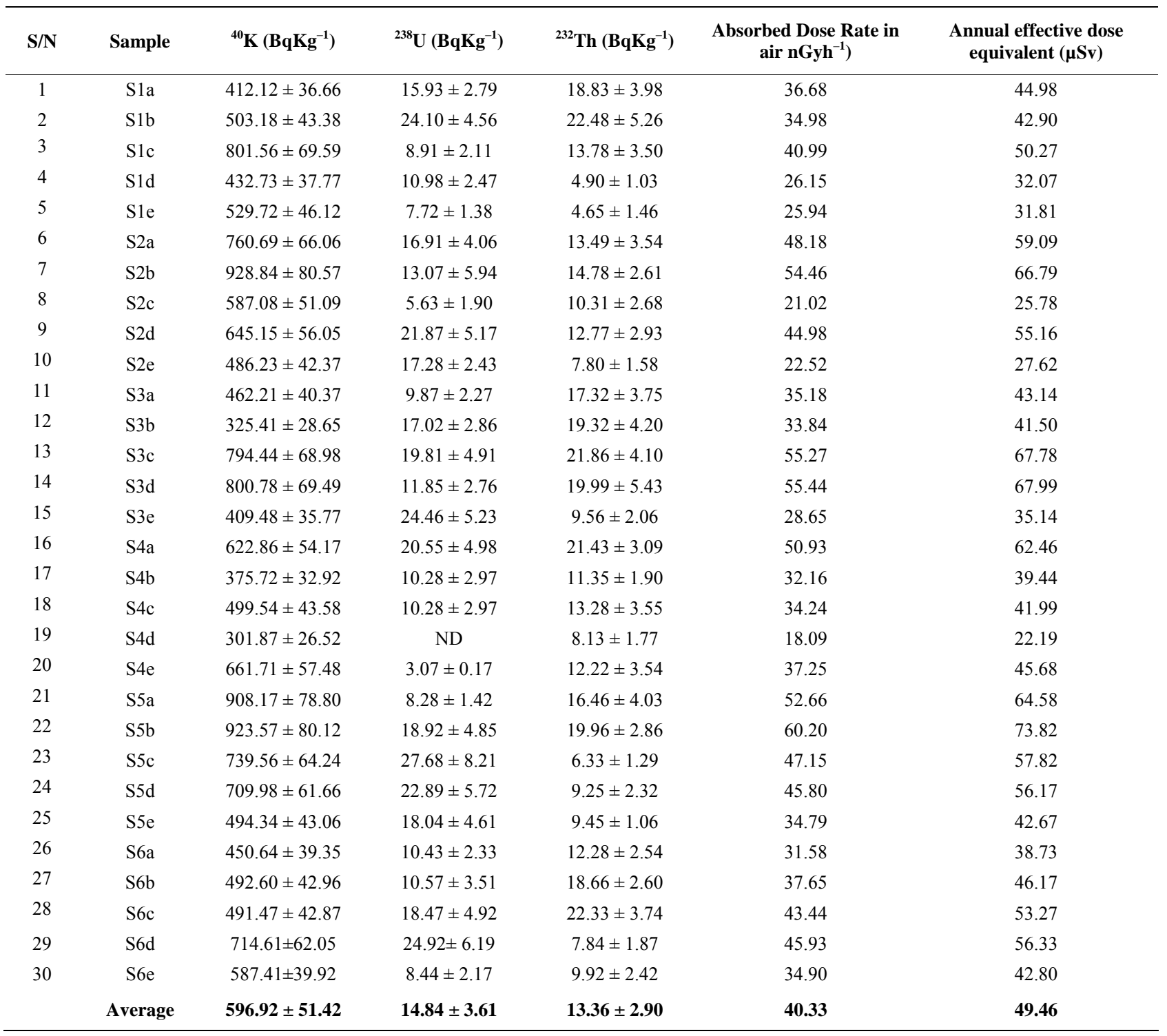




\section{Discussion of Results}

Figure 2 shows the activity concentrations of ${ }^{40} \mathrm{~K},{ }^{238} \mathrm{U}$ and ${ }^{232} \mathrm{Th}$ in the 30 samples collected. The activity concentration of the collected soil samples compare reasonably well with the worldwide average concentrations of 400, 40, $40 \mathrm{Bqkg}^{-1}$, respectively [17] as reported by UNSCEAR. Also, these values for $U$ and $T h$ values are less than the world average while the soil in Abuja has higher concentrations of $\mathrm{K}$, perhaps due to the geological features of the city.

Figure 3 shows the AEDE values which were found to be between 22.19 and $73.82 \mu \mathrm{Sv}$ for Kuje and airport respectively while the average AEDE of $49.46 \mu \mathrm{Sv}$ is recorded. This value represents about $70.7 \%$ of the world average of $70 \mu \mathrm{Sv}$ (UNSCEAR, 1988). However, this value is just about $4.9 \%$ of the $1.0 \mathrm{mSv}$ recommend by the International Commission on Radiological Protection (ICRP, 1992) [18] as the maximum permissible AEDE for members of the public. This value clearly establishes the fact that there is no potential danger to the health of the citizenry of the Abuja Federal Capital Territory (FCT) due to radiological hazards.

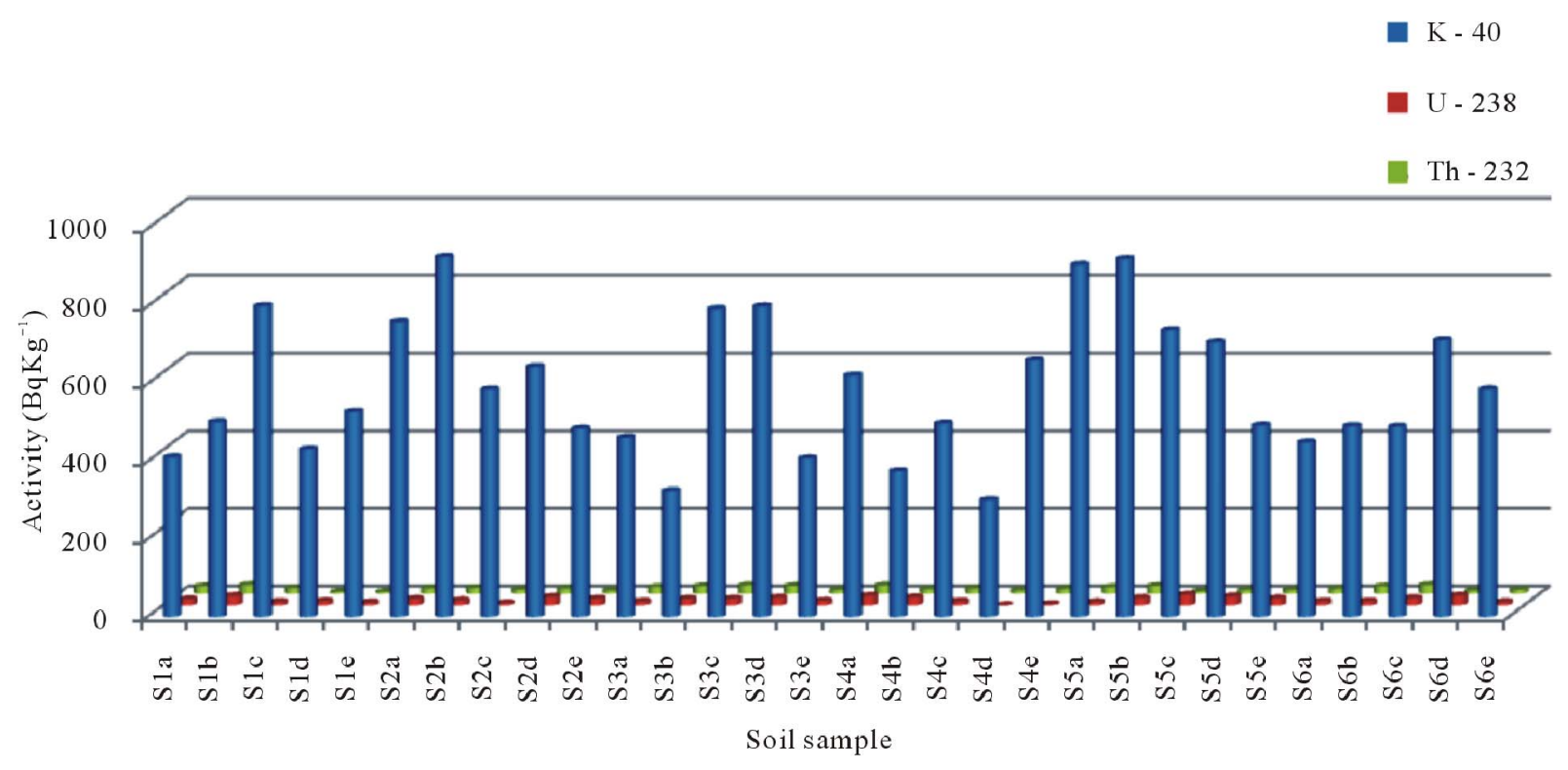

Figure 2. Pictorial representation of the ${ }^{40} \mathrm{~K},{ }^{238} \mathrm{U}$ and ${ }^{232} \mathrm{Th}$ in the samples.

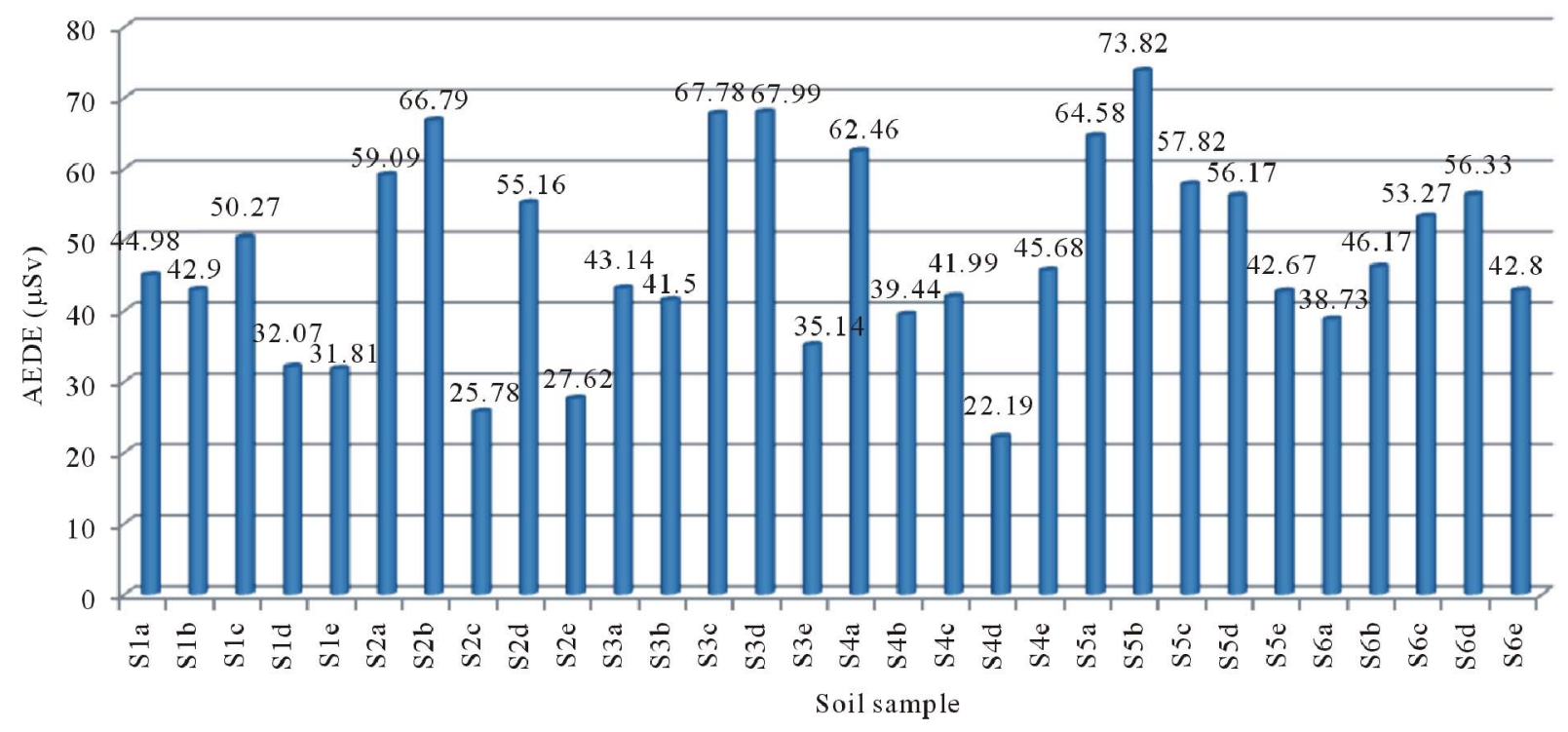

Figure 3. Pictorial representation of the Annual Effective Dose Equivalent (AEDE). 


\section{Conclusion}

A total of 30 measurements were made covering the sampling stations in Abuja FCT comprising six area councils. The concentration of the radionuclides ${ }^{40} \mathrm{~K},{ }^{238} \mathrm{U}$, and ${ }^{232} \mathrm{Th}$ in soil samples were measured. The absorbed dose rate and annual effective dose equivalent were also calculated. The value of the annual effective dose equivalent of $40.33 \mathrm{nGyh}^{-1}$ is low compared to the world average of $70 \mu \mathrm{Sv}$ specified by UNSCEAR for an outdoor effective dose, hence the chances of radiological hazards to the health of the populace is generally low. However, it may be necessary to determine the radioactivity concentrations in soils of other adjoining states bordering Abuja city to be able to draw better conclusions on the radioactivity levels in the central part of Nigeria. Also, the results may be useful as reference data for monitoring possible radioactivity pollutions in the future.

\section{Acknowledgements}

The technical support of the Center for Energy Development of the Obafemi Awolowo University, Ile-Ife, Nigeria is appreciated. Mrs. Awodugba C.S. efforts at proof-reading the manuscript is also equally valued.

\section{REFERENCES}

[1] M. Abusini, K. Al-ayasreh and J. Al-Jundi, "Determination of Uranium, Thorium, and Potassium Activity Concentrations in Soil Cores in Araba Valley, Jordan," Radiation Protection Dosimetry, Vol. 128, No. 2, 2008, pp. 213-216. doi:10.1093/rpd/ncm327

[2] S. Selvasekarapandian, N. M. Manikandan, R. Sivakuman, et al., "Natural Radiation Distribution of Soils at Kotagiri Taluk of the Nilgiris Biosphere in India," Journal of Radioanalytical and Nuclear Chemistry, Vol. 252, No. 2, 2002, pp. 429-435.

[3] M. Tzortzis and H. Tsertos, "Determination of Thorium, Uranium and Potassium Elemental Concentration in Surface Soils in Cyprus," Journal of Environmental Radioactivity, Vol. 77, No. 3, 2004, pp. 325-338. doi:10.1016/i.jenvrad.2004.03.014

[4] United Nation Scientific Committee on the Effects of Atomic Radiation (UNSEAR), "Source, Effects and Risks of Ionizing Radiation," New York, 2000.

[5] H. Florou, and P. Kritidis, "Gamma Radiation Measurements and Dose Rate in the Coastal Areas of a Volcanic Island. Aegean Sea, Greece," Radiation Protection Dosimetry, Vol. 45, No. 1-4, 1992, pp. 277-279.

[6] A. Matiullah, Sh. Ur-Rehman, A. Ur-Rehman and M. Faheem, "Measurement of Radioactivity in the Soil of Behawalpur Division, Pakistan," Radiation Protection Dosimetry, Vol. 112, No. 3, 2004, pp. 443-447. doi:10.1093/rpd/nch409
[7] J. C.Fernandez, , Robayna, B., Allendo, A., Poffijin, A. and Hernandez-Armas, "Natural Radiation in Tenerife (Canary Islands)," Radiation Protection Dosimetry, Vol. 45, No. 1-4, 1992, pp. 545-548.

[8] I. C. Okeyode and I. P. Farai, "Measurement of Activity Concentrations of Natural Radionuclides in the Topsoil of IITA Ibadan, Nigeria by Gamma-Ray Spectrometry," Journal of Radiological Protection," Vol. 27, No. 3, 2007, pp. 333-347.

[9] N. N. Jibiri and H. U. Emelue, "Soil Radionuclide Concentrations and Radiological Assessment in and around a Refining and Petrochemical Company in Warri, Niger Delta," Nigeria Journal of Radiological Protection, Vol. 28, No. 3, 2008, pp. 361-368. doi:10.1088/0952-4746/28/3/006

[10] G. O. Avwiri, "Determination of Radionuclide Levels in Soil and Water around Cement Companies in Port Harcourt, Nigeria," Journal of Applied Sciences \& Environmental Management, Vol. 9, No. 3, 2005, pp. 27-29.

[11] A. O. Awodugba, and P. Tchokossa, "Assessment of Radionuclide Concentration in Water Supply from Boreholes in Ogbomosoland, Western Nigeria," Indoor and Built Environment, Vol. 17, No. 2, 2008, pp. 183-186. doi:10.1177/1420326X08089551

[12] O. S. Ajayi, "Distribution of Natural Radioactivity in Rocks from Ikogosi in Ekiti, South West in Nigeria and Its Radiological Implication," Heath Physics, Vol. 70, No. 2, 2000, pp. 192-195. doi:10.1097/00004032-200008000-00013

[13] B. E. Kogo, E. N. Gajere, J. K. Ogunmola and J. O. Ogbole, "Neutron Activation Analysis of Soil Samples from Different Parts of Abuja Metropolis," Middle-East Journal of Scientific Research, Vol. 4, No. 4, 2009a, pp. 254-262.

[14] B. E. Kogo, E. N. Gajere, J. K. Ogunmola and J. O. Ogbole, "Neutron Activation Analysis of Leaf Samples from Different Parts of Abuja Metropolis," Middle-East Journal of Scientific Research, Vol. 4, No. 4, 2009b, pp. 245-253.

[15] International Atomic Energy Agency (IAEA), "Uranium Deposit in Metamorphic Rocks International Atomic Energy Agency", Vienna, 1989.

[16] H. L. Beck, "The Physics of Environmental Radiation Fields," Proceedings of the 2nd International Symposium on the Natural Radiation Environment II, Houston, 1972, CONF-720805P2.

[17] United Nations Scientific Committee on the Effect of Atomic Radiation (UNSCEAR), "Sources and Biological Effects of Ionizing Radiation,” New York, 1988.

[18] International Commission On Radiological Protection (ICRP), "The 1990-91 Recommendations of the International Commission on Radiological Protection," Publication 60, Vol. 21, No. 1-3, 1992. 